\title{
Learning Management System (LMS) Sebagai Aplikasi Pengembangan Materi Interaktif Pada mata Kimia Lingkungan dengan Metode Computer Assisted Instruction
}

\author{
Aulia Sanova \\ Program Studi Pendidikan Kimia, Jurusan PMIPA FKIP Universitas Jambi \\ e-mail : au_sanova@yahoo.com
}

\begin{abstract}
ABSTRAK
Proses pembelajaran dalam LMS Kimia Lingkungan mengakomodasi beberapa konten dengan berbagai vitur yaitu course content yang mencakup artikel, materi modul yang dikemas dalam bentuk flash animasi, tugas/ujian, dan video pembelajaran mata kuliah Kimia Lingkungan dari dosen, kalender untuk deadline dan penugasan untuk mengukur pencapaian mahasiswa. Penelitian ini bertujuan menunjukkan desain produk e-learning berbasis LMS menggunakan aplikasi moodle yang sesuai dan layak dikembangkan untuk mata kuliah Kimia Lingkungan. Penelitian ini menggunakan desain penelitian dan pengembangan (Research and Development) modifikasi Sugiyono. Subyek penelitian yaitu mahasiswa Program Studi Pendidikan Kimia yang ditentukan secara convenience sampling. Data yang diambil adalah kelayakan dari segi materi dan media serta tangggapan mahasiswa terhadap produk yang telah dikembangkan melalui angket. Tanggapan ahli menunjukkan e-learning berbasis Moodle sangat layak dari segi media dan layak dari segi materi. Hasil angket tanggapan siswa pada uji coba skala kecil menunjukkan bahwa mayoritas mahasiswa memberikan tanggapan positif dimana para mahasiswa sangat tertarik dan memberikan respon jika aplikasi LMS moodle merupskan bentuk inovasi dalam alternatif proses pembelajaran. Produk final $e$ learning berbasis Moodle berisi materi yang dikemas dalam bentuk interaktif, penugasan dan diskusi. Berdasarkan hasil analisis dan pembahasan dapat disimpulkan bahwa LMS berbasis Moodle layak dan efektif diterapkan pada perkuliahan Kimia Lingkungan.
\end{abstract}

\section{Kata Kunci : Learning Management System, Kimia Lingkungan, CAI}

\section{PENDAHULUAN}

Pendidikan merupakan salah satu sarana untuk meningkatkan kecerdasan dan keterampilan manusia. Pendidikan dapat mengembangkan kemampuan pribadi, daya pikir dan tingkah laku yang lebih baik. Pembelajaran melalui metode ceramah tanpa menggunakan media menimbulkan banyak mahasiswa yang kurang memperhatikan dosen karena terkesan monoton. Kondisi seperti ini akan berakibat buruk terhadap prestasi belajar mahasiswa, dimana pada akhirnya kompetensi yang ditetapkan di awal perkuliahan tidak tercapai (Hidayati, 2016). Dalam rangka meningkatkan mutu pendidikan, strategi maupun metode belajarpun ditingkatkan. Salah satu upaya untuk meningkatkan kualitas pendidikan adalah dengan metode Computer-Assisted Instruction (CAI).

CAI (Computer-Assisted Instruction) adalah program pengajaran berbantuan komputer yang telah banyak digunakan oleh para pendidik sebagai alternatif pembelajaran. Adapun alternatif- alternatif yang terdapat pada CAI (Computer-Assisted Instruction) sebagai pusat 
informasi transmisi yang bersifat spesifik, kompleks, dan praktikal, dan proses transmisi yang dapat dimulai sedini mungkin pada peserta didik sebagai sumber belajar yang interaktif dan komunikatif, dengan struktur kelas yang dinamis dan dapat dipergunakan oleh para pendidik sebagai drill and practice, simulasi dan tutorial yang dapat diaplikasikan lewat komputer. Dengan menggunakan metode pembelajaran seperti ini, para mahasiswa dapat lebih tertarik untuk belajar.

Dampak positif perkembangan teknologi yang dapat dirasakan secara nyata dalam bidang pendidikan adalah aplikasi pelaksanaan pembelajaran jarak jauh menggunakan e-learning. Elearning disusun dengan tujuan menggunakan sistem elektronik atau komputer sehingga mampu mendukung proses pembelajaran melalui komunikasi daring (Allen, 2013). Sistem pembelajaran seperti ini mendapatkan materi tanpa harus bertatap muka dengan dosen didalam kelas, proses pembelajaran bisa di atur sesuai dengan waktu belajar yang diinginkan dan peserta didik dapat mengakses ilmu secara mandiri baik di lingkungan kampus maupun rumah, sehingga proses belajar tidak lagi hanya mendengarkan uraian materi dari dosen tetapi materi bahan ajar dapat divisualisasikan dalam berbagai format dan bentuk yang lebih dinamis dan interaktif (file, video, musik, animasi, dll) (Ruli, 2009). Implementasi e-learning pada proses perkuliahan telah berhasil meningkatkan motivasi dan hasil belajar mahasiswa (Ali, 2007).

Salah satu perangkat e-learning yang sangat penting peranannya adalah Learning Management System (LMS). LMS adalah suatu aplikasi perangkat lunak (software) untuk keperluan kegiatan proses belajar mengajar dan kegiatan yang terhubung secara online maupun offline (Romi, 2008). LMS menawarkan sistem pembelajaran inovasi yang mencakup dalam bidang teknologi informasi. Metode pembelajaran e-learning dengan menggunakan learning management system dan memanfaatkan aplikasi open source yang dapat diunduh secara gratis di internet. Pembelajaran berbasis LMS dikembangkan secara dinamis (dinamic e-learning) yang berisi kemasan materi-materi dalam bentuk multimedia (teks, animasi, video dan sound) yang diberikan sebagai supplement dan enrichment bagi pengembangan kompetensi pembelajar (Munir, 2010).

Teknologi yang sudah berkembang sangat pesat sudah seharusnya dijadikan sebagai salah satu cara untuk mempermudah proses pembelajaran salah satunya dapat di rancang dan di kembangkan pada mata kuliah Kimia Lingkungan dimana karakteristik materi ini memberi wawasan mahasiswa untuk menjaga lingkungan nya dan membahas isu-isu penting dalam perubahan iklim dunia, seperti global warming, hujan asam, berbagai kompartemen tercemar di lingkungan perairan, udara dan tanah dari segi tinjauan kimia dan proses transformasi kimia yang berlangsung di lingkungan dari berbagai aktivitas yang menyebabkan terjadinya penurunan kualitas lingkungan. Sehingga dalam pembelajarannya di butuhkan keterampilan pengetahuan konkrit berupa visualisasi tentang gambar, animasi, video yang menjelaskan tentang fenomena dan proses senyawa-senyawa kimia organik maupun an organik yang terpapar dilingkungan, sehingga dibutuhkan suatu media dan metode yang tepat agar pembelajaran semakin menyenangkan, interaktif dan dapat meningkatkan aktivitas mahasiswa dalam mengikuti proses pembelajaran. 
Media aplikasi LMS memiliki peran yang besar dalam mengefektifkan komunikasi dan interaksi antara dosen dan mahasiswa. Proses pembelajaran dalam LMS Kimia Lingkungan mengakomodasi beberapa konten dengan berbagai vitur yaitu course content yang mencakup artikel, materi modul yang dikemas dalam bentuk flash animasi, tugas/ujian, dan video pembelajaran mata kuliah Kimia Lingkungan dari dosen, kalender untuk deadline tugas dan ujian mata kuliah, evaluasi pembelajaran dan penugasan untuk mengukur pencapaian mahasiswa, grade book/rapor untuk memperlihatkan skor yang diperoleh mahasiswa dan pustaka media.

\section{METODE PENELITIAN}

Pengembangan Learning Management System moodle pada mata kuliah Kimia Lingkungan menerapkan metode pengembangan (Research and Development) modifikasi dari Sugiyono (2014).

Adapun langkah-langkah penggunaan metode penggunaan metode pengembangan (Research and Development) dalam penelitian ini adalah :

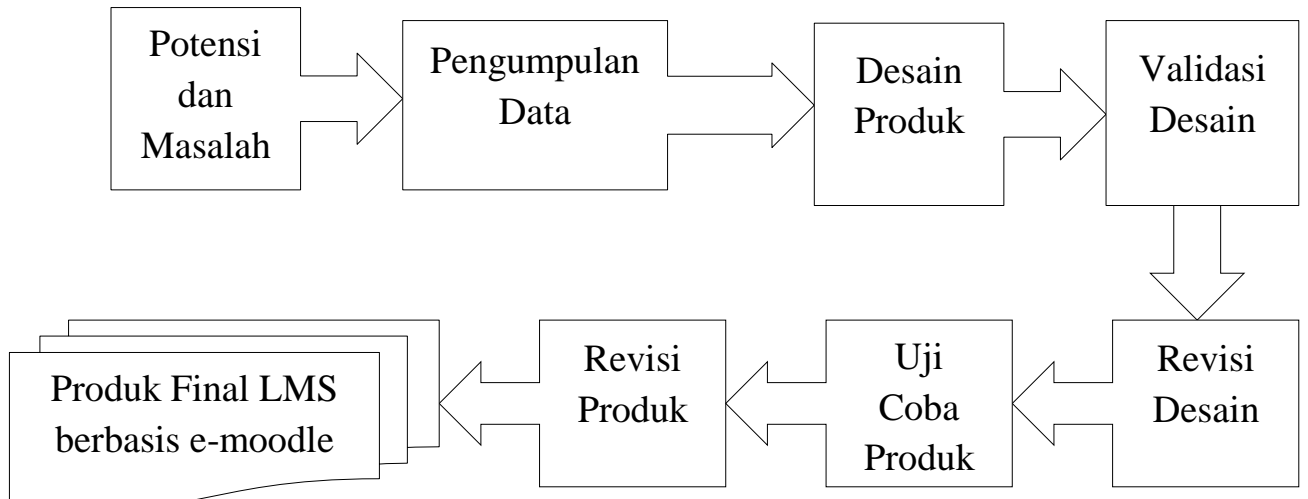

Gambar 1. Langkah-langkah Penggunaan Metode Research and Development (R\&D) Modifikasi dari Sugiyono (2014)

Pelaksanaan uji coba produk media dilakukan setelah produk divalidasi oleh tim ahli dan dinyatakan layak digunakan. Uji coba yang dilakukan dalam tahap pengembang produk adalah uji coba kelompok kecil Mahasiswa Program Studi Pendidikan Kimia sebanyak 10 orang siswa. Pengambilan subyek uji coba ini dipilih berdasarkan karakteristik siswa yang mewakili.

Untuk memperoleh data penilaian kualitas desain media tampilan LMS moodle dan respon mahasiswa dibutuhkan alat pengumpulan informasi berupa angket. Penilaian validasi desain media pembelajaran dan materi yang ditujukan kepada rekan dosen yang ahli dibidangnya untuk mengukur kriteria kevalidan kesesuaian materi dam media. Angket berbentuk rating scale dengan 5 kategori.

Data yang akan diperoleh dalam penelitian ini adalah data kualitatif dan kuantitati. Data kualitatif berupa lembar validasi dari tim ahli yang berisi tanggapan, saran dan masukan. Dimana tangapan, saran dan masukan dari ahli tersebut dipertimbangkkan dan dianalisis 
untuk perbaikan produk.Sedangkan data kuantitatif berdasarkan perhitungan nilai kelayakan yang dinyatakan dengan jumlah interval nilai kelayakan.

Deskriptor yang diberikan pada validasi ahli materi, media dan respon sebanyak 10 item pertanyaan, sehingga secara teoritik akan memperoleh skor minimal 10 dan maksimal 50 dengan panjang interval 8.

Tabel 1. Skor dan Kriteria Validasi Produk dan Respon

\begin{tabular}{ccl}
\hline Skala Nilai & Skor & \multicolumn{1}{c}{ Tingkat Validasi } \\
\hline 5 & $43-50$ & Sangat baik \\
4 & $35-42$ & Baik \\
3 & $27-34$ & Sedang \\
2 & $19-26$ & Tidak baik \\
1 & $10-18$ & Sangat tidak baik \\
\hline
\end{tabular}

Untuk menghitung presentase yang memberikan tanggapan validator dan responder sesuai dengan kriteria tertentu dapat dihitung berdasarkan persentase skor minimum dan maksimum dan di dapat, skor minimum $20 \%$ dan maksimum $100 \%$ dengan rentang interval 16.

Tabel 2. Skala Penilaian Kualifikasi Produk

\begin{tabular}{cc}
\hline Skala Nilai Tingkat Validasi & Tingkat Validasi \\
\hline $85 \%-100 \%$ & Sangat baik/sangat menarik \\
$69 \%-84 \%$ & Baik/menarik \\
$53 \%-68 \%$ & Sedang/cukup \\
$37 \%-52 \%$ & Tidak baik/tidak menarik \\
$20 \%-36 \%$ & Sangat tidak baik/sangat tidak menarik \\
\hline
\end{tabular}

(Sugiyono, 2014).

\section{HASIL DAN PEMBAHASAN}

Hasil pengembangan dari penelitian ini adalah berupa produk ajar berbasis e-learning dengan mengaplikasi platform LMS Moodle dalam proses pembelajaran. Penelitian pengembangan media pada penelitian ini menggunakan prosedur penelitian dan pengembangan (Research and Development) modifikasi dari Sugiyono (2014). Model ini terdiri dari 8 tahap pengembangan yaitu :

\section{Potensi masalah}

Kompetensi mata kuliah kimia lingkungan, pada dasarnya mahasiswa dituntut memahami hal-hal yang berhubungan dengan ilmu yang mempelajari perilaku dan sifat-sifat kimia yang terjadi di kompartemen lingkungan dengan ilmu-ilmu lainnya. Dalam proses pembelajarannya, mata kuliah kimia lingkungan dapat di terapkan dengan memberi pengalaman pembelajaran dalam bentuk diskusi, presentasi oleh dosen, tanya jawab, maupun mengkaji dari berbagai literatur. 
Saat ini arus globalisasi memberi dampak adanya paradigma baru dalam pendidikan yaitu pembelajaran yang sifatnya multiarah dengan memanfaatkan perkembangan teknologi dan informasi atau yang disebut e-learning. Umumnya e-learning menggunakan suatu Learning Management System (LMS) yang berfungsi sebagai platform. Produk e-learning berbasis LMS yang akan dikembangkan dalam penelitian ini adalah Moodle tipe Web Centric Course, dimana sebagian bahan ajar, diskusi, konsultasi, penugasan, dan latihan disampaikan melalui sistim ruang aplikasi. Sedangkan ujian dan sebagian konsultasi, diskusi dan latihan dilakukan secara tatap muka.

\section{Pengumpulan data}

Dalam pengambilan data penelitian terdapat dua tahap metode yang dipakai yaitu studi pustaka dan pengumpulan konten desain multimedia yang memuat konten materi berupa teks, gambar dan video dari beberapa sumber literatur baik dari buku, situs internet, e-book ataupun artikel

\section{Desain produk}

Sistim yang dibutuhkan agar aplikasi Moodle secara offline dapat berjalan dengan baik adalah dengan mempersiapkan instalasi Apache Web Server, PHP, database MySQL atau PostgreSQL. Ketiganya dapat diperoleh dengan mengunduh Xampp.

Desain e-learning berbasis moodle berbasis offline yang dikembangkan memiliki berbagai fasilitas seperti resources dan activities. Dalam fasilitas resources, menyediakan layanan untuk membagi kumpulan bahan ajar yang dapat dipelajari oleh maahsiswa secara mandiri. Sedangkan dalam activites, Moodle memiliki berbagai fasilitas yang dapat berguna mendukung kegiatan pembelajaran, seperti pelaksanaan kuis, penugasan, glossary dan survey.

\section{Validasi desain}

Sebelum penggunaan media e-learning LMS moodle diuji cobakan, maka terlebih dahulu dilakukan validasi materi dan media terkait dengan kesesuaian materi dengan tujuan pembelajaran serta tampilan multimedia pembelajaran dan platfrom moodle itu sendiri. Kegiatan ini disebut juga expert judgment bertujuan untuk mengevaluasi media LMS moodle secara keseluruhan, sehingga diketahui apakah media ini telah sesuai dengan perencanaan.

\section{Revisi desain}

Berdasarkan hasil validasi tersebut, terdapat kemungkinan rancangan produk masih perlu diperbaiki sesuai dengan saran dan masukan validator.

Kriteria hasil penilaian validator materi tahap I adalah sedang dengan skor 34 dan persentase kelayakan sebesar 68\%. Setelah produk tahap pertama direvisi, maka untuk mendapatkan kualitas bahan ajar yang lebih layak ditinjau dari aspek materi, maka dilakukan validasi tahap kedua. Validasi tahap ini, produk dinyatakan baik digunakan sebagai bahan ajar dengan perolehan skor total sebesar 42 dengan persentase kelayakan sebesar 84 . 
Tabel 3. Penilaian Validator Materi Tahap I dan II

\begin{tabular}{|c|c|c|c|}
\hline No. & Indikator & Skor Tahap I & Skor Tahap II \\
\hline 1. & $\begin{array}{l}\text { Kejelasan tujuan pembelajaran (rumusan, } \\
\text { realistis) }\end{array}$ & 4 & 5 \\
\hline 2. & $\begin{array}{l}\text { Relevansi tujuan pembelajaran dengan } \\
\text { kompetensi dalam kurikulum }\end{array}$ & 4 & 4 \\
\hline 3. & Kesesuaian materi dengan tujuan pembelajaran & 3 & 4 \\
\hline 4. & Kontekstualitas dan aktualitas & 3 & 5 \\
\hline 5. & Kelengkapan dan kualitas e-learning & 4 & 4 \\
\hline 6. & Kedalaman materi & 3 & 5 \\
\hline 7. & Kemudahan memahami materi & 3 & 4 \\
\hline 8. & Sistematis, runtut, dan alur logika jelas & 3 & 3 \\
\hline 9. & Kejelasan uraian, pembahasan dan contoh & 4 & 5 \\
\hline 10. & $\begin{array}{l}\text { Inovasi penyajian materi ikatan kimia dalam } \\
\text { media pembelajaran }\end{array}$ & 3 & 3 \\
\hline & Total Skor & 34 & 42 \\
\hline & \% Kelayakan & 68 & 84 \\
\hline & Kriteria & Sedang & Baik \\
\hline
\end{tabular}

Untuk produk pengembangan bahan ajar berbasis moodle, pada tahap pertama validator menyatakan secara keseluruhan produk media berada dalam kriteria sedang dengan skor 32 dan persentase kelayakan sebesar $64 \%$. Pada penilaian tahap kedua media sudah dinyatakan baik dengan skor 45 dan persentase kelayakan sebesar $90 \%$.

Tabel 4. Penilaian Validator Desain Media Berbasis Moodle Tahap I dan II

\begin{tabular}{clcc}
\hline No. & \multicolumn{1}{c}{ Indikator } & Skor Tahap I & Skor Tahap II \\
\hline 1. & Susunan tampilan dikemas secara baik & 3 & 4 \\
2. & Tampilan teks dikemas secara baik & 3 & 5 \\
3. & Tampilan gambar telah sesuai & 2 & 4 \\
4. & Suara pada tampilan multimedia terdengar jelas & 4 & 5 \\
5. & Materi yang disajikan sesuai dengan kurikulum & 4 & 4 \\
6. & Tombol navigasi mudah di gunakan & 3 & 5 \\
7. & Terdapat tampilan tugas & 4 & 4 \\
8. & Terdapat fitur quis sebagai bentuk penugasan & 4 & 4 \\
9. & Media di kemas secara interaktif & 2 & 5 \\
10. & Fitur prsentasi dikemas secara baik & 3 & 5 \\
\hline \multicolumn{4}{c}{ Total Skor } \\
\% Kelayakan & $\mathbf{3 2}$ & $\mathbf{4 5}$ \\
& Kriteria & $\mathbf{6 4}$ & $\mathbf{9 0}$ \\
\hline
\end{tabular}

Adapun saran-saran yang diberikan oleh validator desain media pembelajaran berbasis moodle adalah pada tampilan awal, untuk setiap kajian pokok bahasan perlu di beri penjelas 
sebagai media penyampai pesan terkait konsep awal materi dan pengaturan ukuran tulisan yang terlalu padat dan tidak berjarak.

6. Uji coba produk

Setelah dilakukan revisi, tahap selanjutnya adalah mengujicobakan produk. Uji coba skala kecil. Tasri (2011) mengemukakan pentingnya uji coba dalam pengembangan produk. Uji coba dalam pengembangan produk merupakan salah satu aktivitas yang tujuannya adalah untuk mencari sebanyak-banyaknya kesalahan, error maupun defect.

Berdasarkan hasil uji respon mahasiswa, produk media pembelajaran dengan memanfaatkan aplikasi moodle ini di nilai baik dan menarik, yang didapat dari hasil perhitungan menggunakan skala likert dengan skor 42,1 dari skor maksimal 50 dengan persentase $84,2 \%$, sehingga pengembangan ini menghasilkan produk berupa pembelajaran berbasis LMS moodle yang layak digunakan dalam perkuliahan kimia lingkungan.

Komentar dan saran siswa secara umum adalah pembelajaran dengan menggunakan moodle merupakan pembelajaran yang dapat mengembangkan fleksibilitas kognitif, karena memudahkan mahasiswa untuk mengakses informasi tidak hanya dari pertemuan tatap muka saja, namun juga dari sumber apikasi sistem berbasis open source. Hal ini memudahkan mahasiswa untuk belajar secara mandiri, dimana penggunaan e-learning memberi kesempatan untuk memperdalam materi dan dapat melakukan diskusi lanjutan di luar kelas. Sejalan dengan Anitah (2008), yang mengemukakan bahwa antara pendidik dan siswa tidak hanya dapat mengakses buku teks di sekolah, tetapi dapat memperoleh informasi dari jarak jauh, mengakses pustaka, dokumen-dokumen elektronik ke seluruh dunia untuk memperkaya studinya melalui e-learning.

7. Produk final.

Produk e-learning berbasis Moodle merupakan menu utama pada web pengantar dengan alamat kimia.com. Seri e-learning yang dikembangkan adalah Moodle 2.8 versi offline. Tampilan produk ini terdiri dari halaman menu, tampilan materi, kuis, penugasan dan glossary.

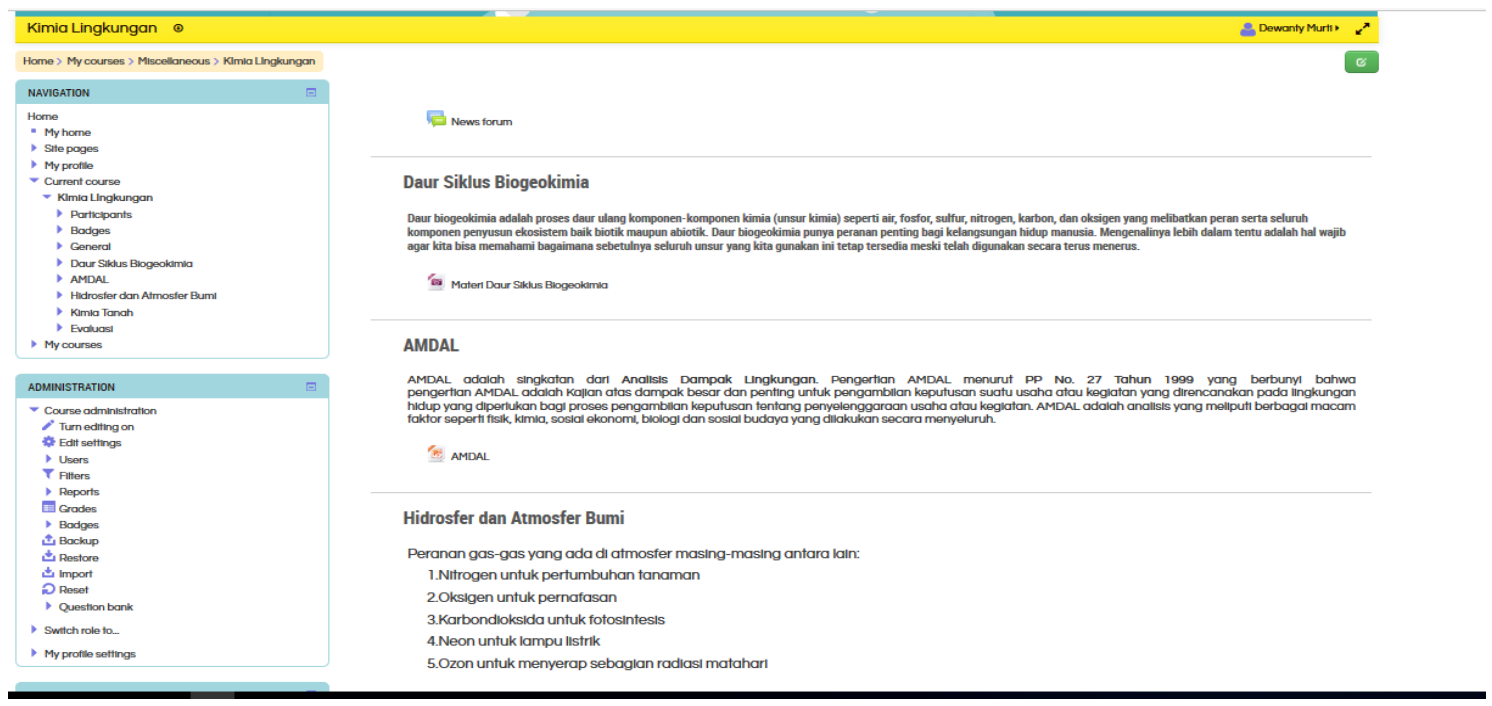

Gambar 1. Tampilan Source Pada Materi Bahan Ajar 


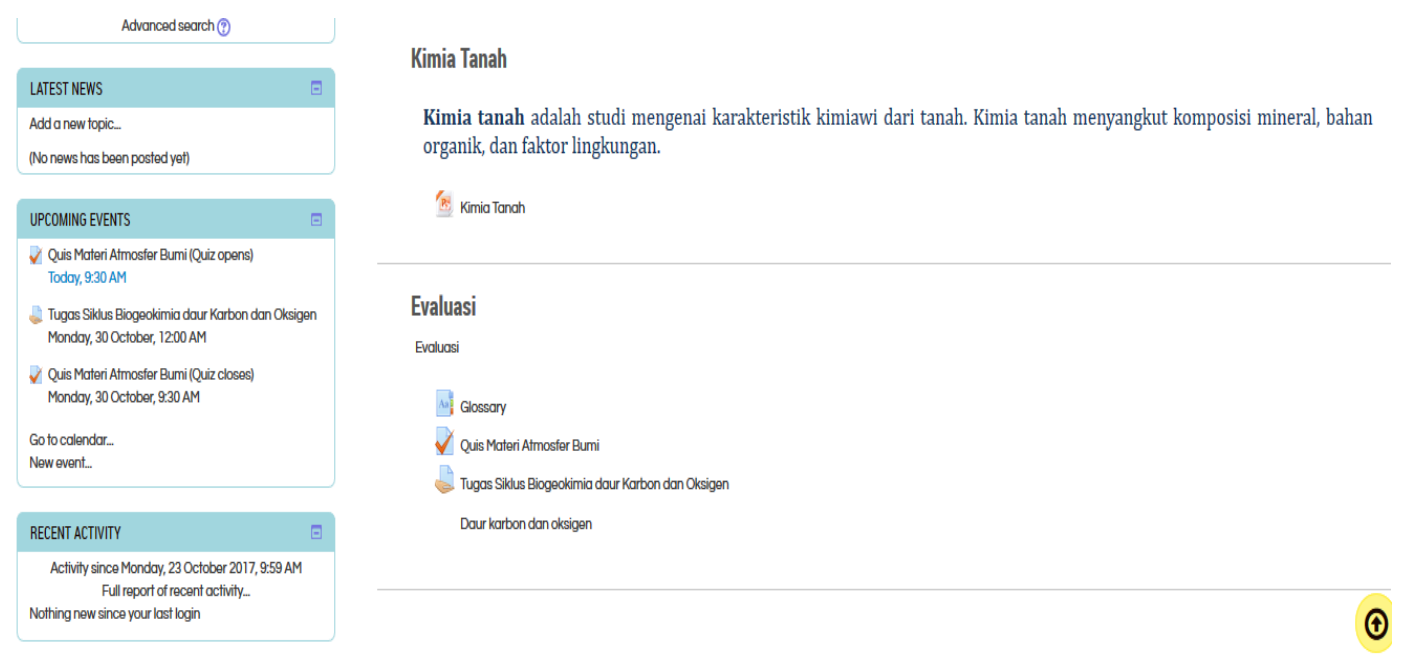

Gambar 2. Tampilan Aktivitas Pada Aplikasi Moodle

\section{KESIMPULAN DAN SARAN}

Penelitian ini merupakan penelitian pengembangan metode Research and Development modifikasi dari Sugiyono yang terdiri dari 4 tahap yaitu potensi masalah,pengumpulan data, desian produk, validasi desain, revisi, uji coba dan produk final. Namun dalam penelitian ini dikarenakan terkendala oleh waktu, maka proses pengembangan untuk uji coba produk hanya dilakukan pada kelompok kecil saja. Pada tahap penilaian validasi produk, penilaian validasi materi media dan respon mahasiswa dinilai baik.

Pengembangan media berbasis moodle dapat di kembangkan berbasis web online sehingga dapat menaikkan nama instansi namun harus disertai dengan jaringan hosting yang memadai. Pembelajaran dengan berbasis online diharapkan dapat menambah interaktivitas siswa dalam melakukan kegiatan pembelajaran secara mandiri walaupun secara maya.

\section{DAFTAR PUSTAKA}

Allen, M, 2013, Michael Allen's Guide to Elearning. Canada: John Wiley \& Sons.

Anitah S. 2008. Media Pembelajaran. Surakarta: Unnes Press.

Mayer, R.E. 2009. Multimedia Learning Prinsip-prinsip, Aplikasi dan Tiga Asumsi Teori Kognitif Multimedia Learning. Yogyakarta: Pustaka Pelajar

Munir, 2010, Kurikulum Berbasis Teknologi Informasi dan Komunikasi, Bandung, Alfabeta, h. 202.

Hidayati, I, P, 2016. Optimalisasi Pengembangan Blended Learning Berbasis Moodle Untuk Matakuliah Mikrobiologi., Jurnal Inspirasi Pendidikan Universitas Kanjuruhan Malang Volume 6 Nomor 2.Sugiyono. 2014. Metode Penelitian Pendidikan. Bandung: Alfabeta Tasri L. 2011. Pengembangan bahan ajar berbasis web. Jurnal MEDTEK 3 (2):1-8. 